\title{
Algerian Women's Būqālah Poetry: Oral Literature, Cultural Politics, and Anti-Colonial Resistance
}

\author{
Susan Slyomovics \\ University of California, Los Angeles
}

\begin{abstract}
Büqālah refers both to a ceramic pitcher as well as to poems ritually embedded in the traditional, favorite, divinatory pastime associated with women city dwellers of specific Algerian towns such as Blida, Cherchell, Tlemcen, Constantine, and Algiers. This essay considers the shift from orality to a written archive of French and Algerian collections of būqālah poems by focusing on analyses of Algerian Arabic oral literature as an expression of feminine cultural protest and resistance to the domination of language policies under French colonialism. What are the ways in which an intimate ritual—one linked to orality, the divinatory, women's poesis, and the Algerian Arabic dialect—begins to carry political meanings during the War of Independence and in post-1962 independent Algeria? Contributing to the circulation and creation of new meanings, forms, and venues for būqālah poetry are Algerian radio and television broadcasts, Internet postings, and the publication of the 1962 French poem "Boqala" by Djamila Amrane.
\end{abstract}

\section{Keywords}

būqālah - Algeria - women - oral poetry - dārijah - Djamila Amrane - French colonialism - gender - folklore

Būqālah designates at one and the same time a material ceramic object as well as the immateriality of a poem performed and ritually embedded in the traditional, favorite, divinatory pastime of many Algerian women. Thus, būqālah (also spelled in the literature as bouqala, boukala, boqala, and in the plural as bwaqel, bawāqal, boukalates) is the name of a porous clay water pitcher with two handles, employed to this day to divine the future, especially to predict 
the fate of sons, husbands and future loves. ${ }^{1}$ The $b \bar{q} q \bar{a} l a h$ pitcher and poem are intimately linked through women's physical touch, poetic creativity, and a belief in the efficacy and magical powers of divination. As the name of the short verse poem of approximately four to ten lines or longer, the būqālah is rhymed, polysemic, and transmitted orally by Algerian woman in vernacular Algerian Arabic (dārijah), while the clay būqālah pitcher twirls in the women's hands. It is a poetic and ritual practice long associated with the female inhabitants of specific cities such as Blida, Cherchell, Constantine, Tlemcen, and Algiers.

Among the scholars, primarily French and Algerian, who have collected and analyzed būqālah poetry are Joseph Desparmet, Saadeddine Bencheneb, Kaddour M'Hamsadji, William Marçais, Mourad Yelles-Chaouche, Aida Bamia, Aziza Boucherit, Mohamed Kacimi, and Martine Bertrand. ${ }^{2}$ French colonialera contributions led to the creation of texts that transmitted spoken Algerian

1 The word $b \bar{u} q \bar{a} l$ is said to derive from the French word bocal, or "jar" according to Adrien Barthélemy, Dictionnaire arabe-francais: Dialectes de Syrie: Alep, Damas, Liban, Jérusalem (Paris: Geuthner, 1935), vol. 1, p. 56. Throughout this essay, English translations are mine unless otherwise noted. In the footnotes that follow, bibliographic information is provided about Arabic transcriptions and French translations from the core collections. For personal and place names, I retain the prevailing French transcription system in use throughout the Maghrib, for example Ahmed Taleb (not Ahmad Țālib). Exceptions are places already established in English, for example Fez, not Fès (French transcription) or Fās (literary Arabic transcription).

2 A partial bibliography includes the extensive writings of Mourad Yelles-Chaouche (who also publishes as Mourad Yelles) cited throughout this essay. See also Geneviève Khedis, "Approche linguistique et sociologique d'un genre particulier de poésie féminine: La boqala, pratiquée au cours des rituels divinatoires féminins en Algérie," Littérature orale: Actes de la Table Ronde, Juin 1979 (Algiers: Office des Publications Universitaires, 1982): 76-80; Aziza Boucherit. "Littérature orale et divination: Le passage à l'écrit," Cahiers de littérature orale 23 (1988): 157-175; William Marçais, Le dialecte arabe parlé à Tlemcen (Paris: E. Leroux, 1902); Kaddour M'Hamsadji, Jeu de la bouqala: Contribution à une meilleure connaissance de ce divertissement éducatif et populaire (Algiers: Office des publications universitaire, 1989); Joseph Desparmet, Coutumes, institutions, croyances des Musulmans de l'Algérie (Algiers: Imprimeries La Typo-Litho et J. Carbonel, 1948); and Joseph Desparmet, Enseignement de l'arabe dialectal d'après la method directe: Coutumes, institutions, croyances des indigènes de l'Algérie (Algiers: A. Jourdan, 1913); Mohamed Kacimi and Rachid Koraichi, Bouqala: Chants des femmes d'Alger (Paris: Editions Thierry Magnier, 2006); Aida Adib Bamia, The Graying of the Raven: Cultural and Sociopolitical Significance of Algerian Folk Poetry (Cairo: The American University in Cairo Press, 2001); Martine Bertrand, Le jeu de la boqala (Paris: Publisud, 1983); Saadeddine Bencheneb, "Chansons de l'escarpolette," Revue africaine 89 (1945): 89-102; Saadeddine Bencheneb, "Des moyens de tirer des présages au jeu de la buqala," Annales de l'Institut d'Etudes Orientales d'Alger 14 (1956): 19-111; and Jacques Grand'Henry, "Divination et 
Arabic either in Arabic script modified for the dialect or Latin alphabet transcriptions. These translations and dialect transcriptions tend to focus on structural, metrical, and content matters internal to the text. In retrospect, little is provided about topics relevant to contemporary folklorists, literary critics and anthropologists. For example, who were and are the women storytellers and poets, what is known about the oral culture that produced these texts, and were the redacted texts elicited from informants in special situations? More questions arise about French translations from spoken Algerian Arabic that stray far from the literal. In addition, the accuracy, or inaccuracy, of pronunciation protocols varied according to the transliteration system, while documentation about style, prosody, and rhythms of the chanted, often improvised poetry is absent. Despite minimal biographical knowledge about individual women poets, nonetheless, French colonial-era ethnographers and administrators, who were steeped in cultural and ideological justifications for France's mission civilisatrice, remained entranced by Algerian women's rites and superstitions and the attendant possibilities for gaining access to female worlds through folklore research. This did not prevent them from engaging in efforts to overturn the very worldview of the "natives" (indigènes to use colonial terminology) that these creative folk items expressed, all the while presenting a nostalgic and idyllic women's space divorced from the everyday realities of settler colonialism. What they furnished were texts and translations inattentive to individual improvisatory practices and framed by descriptions of a generic, idealized būqālah ritual.

Although current perspectives in folklore studies have moved to integrate performance and context as a contrasting approach to solely text-centered colonial folk items, this essay, instead returns to this rich archive of colonialera $b \bar{u} q \bar{a} l a h$ poetry collections in order to focus on specific historical moments when the content, as opposed to the performance context of women's poems, came to serve as vehicles for complex, modern Algerian ways of gendering language and folk heritage. The colonial text-centered approach continues into the era of Internet websites and chat rooms as networked Algerians create an online archive of būqālah poems. Posts are in Arabic script, or more frequently deploy popular, non-standardized, computer-adapted transliterations in which a number stands for a letter ( for example,"3" replaces the letter 'ayn). New media communications replicate while extending the reach of previous collection practices on būqālah poetry, while the rare post appears framed by the writer's memory of past recitations attributed to grandmothers

poésie populaire arabe en Algérie: à propos de quelques Buqala inédites," Arabica 20 (1973): $53-62$. 
and elderly female relatives. Even filmed performances by the official Algerian television broadcasts offer staged būqālah renditions uploaded to YouTube. In 2010, a female presenter, dressed in traditional costume and seated on a brocade divan, provides an example of the ways in which the būqälah might have been chanted. It has been subsequently adapted by the state on the occasion of Ramadan, as if the poet herself incarnates the nation welcoming diasporic Algerians home. ${ }^{3}$

There is no doubt that the transformation of the būqālah ritual into written texts owes much to the powerful reach of French colonial collectors and their published materials, notwithstanding later critiques of their documentation process. In contrast, my topic is to explore Algerian appropriations of its form and function to uncover thematically subversive and dissident content. When the French-created archive of Algerian women's oral traditions was represented and studied in relation to Algerian nationalist aspirations by Algerians, būqālah poetry came to be understood as an expression of resistance to French colonialism despite its traditional content of verses devoted to love and female sexuality.

\section{French Colonial-Era Collections}

One of the earliest descriptions of the ritual in French that included būqālah poems transcribed from Algerian Arabic appeared in 1913 by Joseph Desparmet (1863-1942). A prolific French ethnographer and expert of Algerian Arabic dialect, his language learning handbooks to teach därijah, first published in 1907, are still consulted. ${ }^{4}$ French-born Desparmet resided for fifty years from 1890 to 1940 in Algeria where he taught Latin, then Arabic as a lycée teacher while variously employed in Blida, Algiers, Skikda (then Philippeville) and Tlemcen. He was French colonial Algeria's first advanced student of Arabic dialect, signaled by his award in 1908 of the competitive civil service diploma, agrégé d'arabe,

3 “Boqala fi khater li redj3ou leblad fi ramdane," Canal Algérie tv, YouTube video uploaded August 24, 2010, http://www.youtube.com/watch?v=kqRTZmJupK8. Many more examples can be accessed on YouTube including segments from Algerian ENTV (Enterprise Nationale de Télévision) soap operas that incorporate new versions of the ritual, e.g., būqālah divination using the traditional pot but the message is delivered in written form like Chinese fortune cookies: http://www.youtube.com/watch?v=MUBqlp6cQ98.

4 See Joseph Desparmet, Enseignement de l'arabe dialectal d'après la method directe, 164-172, for examples of transcriptions in Arabic script adapted for Algerian Arabic. His French translations of these same būqālah poems appear elsewhere in Desparmet, Coutumes, institutions, croyances des Musulmans de l'Algérie, 246-253. 
to teach the language. Historian and anthropologist Fanny Colonna deems Desparmet marginal to intellectual life in French-colonial Algeria both because he was a mere high school teacher and his educational specialization was spoken Arabic, a subject about to be displaced by literary (or classical Arabic) in the French-run Algerian school system. Nonetheless, Desparmet's 1932 analysis of the political and sociolinguistic alignments of colloquial Algerian Arabic, literary Arabic, French and Berber/Amazigh was prescient:

We should not believe that in effect ... the battle over language in Algeria comes down to a duel between Arabic and French. Let us imagine a philological map of languages in Algeria, and we shall see that the Maghrebi genius [génie maghrébin] has barricaded itself behind a triple linguistic wall. The first and oldest line of defense is formed by the Berber dialects, which function like so many fortresses... The second protective wall is colloquial Arabic [l'arabe barbaresque ou usuel] which also served the cause of independence against foreign usurpers in the past and could hardly be considered devoid of defensive value. Yet the strategists of Maghrebi Islam [l'Islam maghrébin] doubt its sturdiness, for it is not in step with more recent attitudes. So without downgrading it entirely, it has been relegated to the background. On the frontline face to face with the enemy, the thinkers from among the people and their advisors are at present feverishly building up a defensive and offensive system of classical Arabic [l'Arabe coranique]. ${ }^{5}$

Even as academic practices in colonial Algeria were shifting toward literary Arabic and away from the dialect, Desparmet's focus on Algerian Arabic oral poetry and folklore relegated his academic status and research topics to a configuration of attitudes that folklore studies label the theory of degeneration, devolution, or decay:

The most common devolutionary notion is that folklore decays through time. Another notion is that folklore "runs down" by moving from "higher"

5 Desparmet's quotation translated from French to English includes the parenthetical original French phrase, see Fanny Colonna, "The Lessons of Berque and Desparmet," in Genealogies of Orientalism: History, Theory, Politics, ed. Edmund Burke and David Prochaska (Lincoln, Neb: University of Nebraska Press: 2008), 176. See also Joseph Desparmet, "La réaction linguistique en Algérie," Bulletin de la Société Géographique d'Alger 37 (1932): 173-84. On Desparmet, see also Fanny Colonna, "Questions à propos de la literature orale comme savoir," Revue de l'Occident musulman et de la Méditerranée 22/22 (1976): 17-26. 
to "lower" strata of society. These two notions are by no means mutually exclusive since one can without difficulty imagine that if folklore really moved from "higher" to "lower" strata, it could easily undergo textual deterioration at the same time. ${ }^{6}$

From oral to written, or from Algerian feminine creativity to colonial transcriptions and French translations by male collectors, a sense of entropic decline is assumed and reinforced. What does this mean for the data collected or texts reproduced and presented? One persistent devolutionary consequence was the ability to separate the text from its poet-transmitter, a methodology that inevitably affected the techniques of collecting texts as well as the subsequent redaction, transcription, and translation of oral folklore material. Although collectors may have given pride of place to their use of oral sources direct from the mouth of the "native," at the same time they effectively elided creative female interlocutors, thereby rendering them unknown, hence in a sense muted. Many folklorist-collectors trained in their home countries in Europe would export to their colonies a bias toward the written against the oral in general, and consequently in Algeria, there was an Orientalist tendency to set literary Arabic in opposition to Algerian dialect in their research. When the poet-informant-creators were female, as with büqälah rituals and recitations, a devolutionary reading would assume that women orally recite their poetry because they are as yet too uncivilized to write down their words. In other words, female orality is its own devolutionary proof. ${ }^{7}$

Desparmet's linguistic skills and research projects on the vernacular earned him the name and reputation, accorded by Colonna with historical hindsight, of a "transgressive orientalist," because he was an academic outsider, a "folklorist, a sort of provincial notable who prided himself on being an intellectual." Since his passion for collecting and analyzing Algerian Arabic oral literature was linked to his appreciation of the spoken dialect, his published contributions to būqālah studies resonated in post-independence Algeria, even when he proposed that the dialect constituted the "consolation of a vanquished people."9

6 For a critical discussion of devolutionary theory, see Alan Dundes, "The Devolutionary Premise in Folklore Theory," Journal of the Folklore Institute, 6 (1979): 18-19 [pp. 5-19].

7 For similar arguments concerning French colonial collections in Algeria of the Hilali epic, see Susan Slyomovics, "Methodes de transcription et traduction d'une performance de geste orale arabe." In Le Conte, eds. Pierre Lyon and Paul Perron, (Montreal: Didier, 1987), 127-139.

8 Colonna, "The Lessons of Berque and Desparmet," in Genealogies of Orientalism, 182, 183.

9 Quoted and discussed in Bamia, The Graying of the Raven, 12. 


\section{Decontextualization and Recontextualization}

Fifty years after Desparmet labeled Algerian Arabic the linguistic medium that assuages the colonized, a similar sentiment is articulated by Sarah, the protagonist in novelist Assia Djebar's 1980 Women of Algiers in Their Apartment. Djebar's fictional heroine is a researcher of women's oral literature who notes the postindependence "return to folklore" because "folklore, thus preserved within the family as jam would be, reassures us." ${ }^{10}$ Similarly, writing in the same decades after independence, psychologist Noureddine Toualbi revived Desparmet's analysis in order to valorize historically the roles of feminine rites as linguistic and cultural bulwarks against acculturation to the ongoing French civilizing mission, nothing less than a form of a resistance to changes imposed by colonial administrators. ${ }^{11}$

Beyond therapeutic, consolatory, and sentimental emotions attributed to the $b \bar{u} q \bar{a} l a h$, trends in research began to document the increasing deployment of oral literature and performance in the service of Algerian independence. During Algeria's War of Independence (1954-62), French ethnologist Pierre Bourdieu tracked the rising political consciousness to be found within innovative expressions of oral literature and folk songs that possessed the same social clout and emotional power as a newspaper, heroic epic, or historical account:

... [T] he revolutionary situation awakened a political conscience in all Algerians, of all classes and of all ages, and at the same time led to a new attitude toward society and toward the future that is featured by a great thirst for learning, understanding, information and material progress. One can see a manifestation of this awakening of the political conscience in the appearance of oral literature composed principally of popular songs which exalt the revolutionary struggle. Usually anonymous and inspired by precise events, they sing of the atrocity of war, the heroism of the combatants and of hope for peace. Simple and naïve, these poems in Berber or Arab language, sung in accordance with the modes of the traditional music, are both chronicle and chanson de geste. ${ }^{12}$

\footnotetext{
10 Assia Djebar, Women of Algiers in Their Apartment (Charlottesville, va: University Press of Virginia, 1992), 25.

11 Noureddine Toualbi, Religions, rites et mutations (Algiers: Enterprise Nationale du Livre, 1984). According to sociologist Marnia Lazreg, Toualbi believed that the frequency and increased participation of men in evenings such as the būqālah reflected "cultural anxieties" precipitated by rapid social transformations in the post-colonial era. She points to the post-war feminization of Algerian culture as men appropriated female rituals such as the būqālah for therapeutic purposes. See Marnia Lazreg, The Eloquence of Silence, 178-179.

12 Pierre Bourdieu, The Algerians (Boston: Beacon Press, 1962), 189.
} 
Bourdieu's meditations on Algerian folklore form the concluding chapter to his sociology of Algeria. Entitled "The Revolution within a Revolution," the final pages provide two examples of oral songs he collected from unnamed informants. The second example, which he recorded in Algiers in 1960, is framed by the haunting refrain, the fresh horrors of French colonialism during wartime: "Wherever the Frenchman goes / He leaves behind bloody traces." ${ }^{3}$

Cultural critic and resistance hero Laadi Flici continued this research trajectory to document innovations in interpreting the traditional būqualah. In his memoir, he quotes from the corpus of Desparmet's French translations, a poem he views readily adaptable to Algeria's revolutionary struggle. No word changes are required because he discovers, with hindsight, resistance to any foreign oppressor is already embedded in the genre: ${ }^{14}$

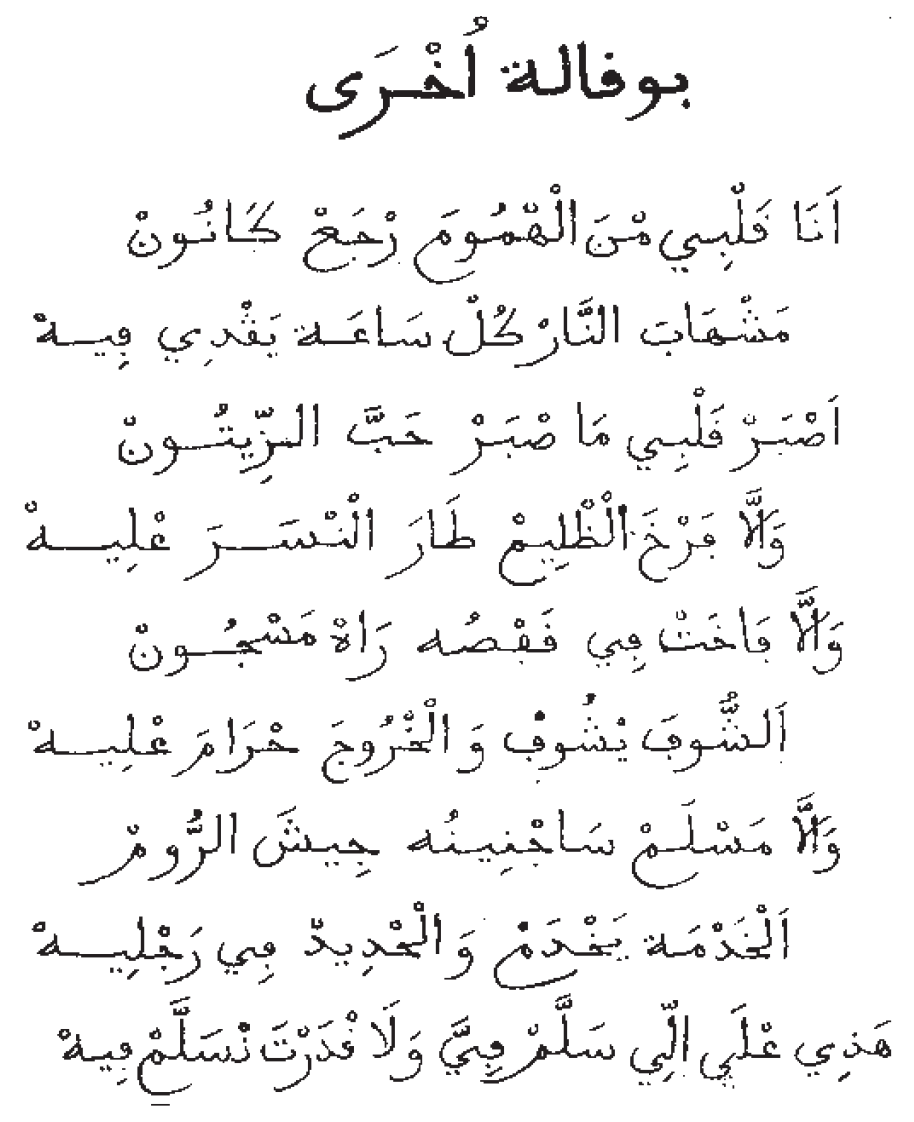

13 Ibid., 189-190.

14 The French translation is in Joseph Desparmet, Coutumes, institutions, croyances des Musulmans de l'Algérie, 249 and the text in Algerian Arabic transcribed in Arabic script is also by Joseph Desparmet, Enseignement de l'arabe dialectal d'après la method directe: Coutumes, institutions, croyances des indigènes de l'Algérie, 128. 
My heart full of worries is like a brazier

where the half-burned logs each moment shoot off high flames

be also patient, $\mathrm{O}$ my heart, until the olive under the press

or the baby ostrich on whom the vulture pounces

or the dove captive in the cage who can watch

and is forbidden to go out

or the Muslim prisoner in the Byzantine army

who suffers laboring

under the weight of irons

This poem applies to whoever gave up on me

While I cannot give up on him. ${ }^{15}$

While Desparmet understood the mere act of speaking Algerian Arabic as an expression of Algerian cultural resistance to the domination of France and the French language, Bourdieu and Flici focused on the transformed and transformative content of improvisational, politicized folk poetry in the vernacular. Once Algeria achieved independence from France in 1962, these approaches underpinned successive Algerian-initiated collections that found new audiences appreciative of women's oral poetry and conveyed to an engaged public through the wide availability of government-sponsored media.

In 1974-75 and again in 1983, the government-run radio system broadcast a series of popular Wednesday evening, one-hour programs devoted to būqālah poems. Listener participation was passionate: the radio station was deluged with poems mailed or phoned in. Writer and radio personality Kaddour M'Hamsadji produced the series and subsequently published the collected poems in book format. He introduces his collection with a description of the generic būqālah ritual followed by an extensive collection of poems in Arabic script and French translation. A summary of the ritual as he recounts it begins with a ceremony of fumigation (tabkhïrah). Seven perfumes commingle in a brazier (kānūn) accompanied by būqālah recitations to invoke good spirits and ward off evil ones. ${ }^{16}$ Audience attendees and the būqälah pitcher pass through fumes of white and black gum benzoin, resins, aloe wood, coriander, incense, and myrrh. The pitcher is filled with water and a mistress of ceremonies recites a poetic invocation $\left(d u^{\prime} \bar{a}^{\prime}\right)$ inviting participants to deposit items in the būqālah pitcher filled with water. A bean may be marked to identify its owner along with any personal objects that have physically touched her body, perhaps a

15 Laadi Flici, Sous les terrasses d'antan: chronique du temps qui passe (Algiers: Entreprise nationale du livre, 1985), 69-70. My English translation.

16 M'Hamsadji, 31-55. 
brooch, earring, bracelet, or hair ornament that will attract the jinn, a supernatural being who is a conduit for divination. The audience, including young female assistants, are asked to think of a specific person and knot a belt, kerchief, or handkerchief ('uqdah) while they focus their thoughts on the absent desired beloved. The mistress of ceremonies recites a poem at the moments of invocation and knot tying.

To trigger poetic and divinatory outcomes, a hand is dipped in the būqālah pitcher and randomly retrieves one of the immersed objects. Once the object's owner is identified, the time comes for poetic inspiration and interpretations on behalf of the ornament's wearer, who is apprised of the poem, its meaning, and how it applies to her and the person in her thoughts. This may be repeated three times for three different petitioners. Then two women hold up the pitcher with their combined four thumbs and make a wish. In their hands, the pitcher in its role as augur and forecaster ( $f \bar{a} l$ or $f e l$ in dialect), might turn right, left, or not at all, signaling the success or failure of their desires. Additional proof for the truth of the divination comes at the end of the evening as the women wait in silence, attending to the random sounds of the city (a baby's cry, the sound of the Qur'an, a car honking) that will be interpreted in support of or against the sense of the poem's words. ${ }^{17}$

As with oral poetic forms cross-culturally, these structured, formulaic lines are inherited, familiar and easy to remember through repeated recitations. The mistress of ceremonies might intersperse regular reminders about the lover's renown - "they tell me about you from Tunis to Cairo" or "they tell me about you from Algiers to Mehdiya." Formulaic lines and oral composition are inextricably linked, allowing poems to unfold during recitations that blend tradition and creativity to ensure novel connections among typical themes inspired by the performance contexts. Būqālah poems are famous for resorting to complex rhetorical, narrative flourishes in which playful exchanges between two lovers are voiced that set the scene for an erotic encounter. Verses may turn on the art itself of creating a būqālah to create a meta-poem about the process of composing poetry rooted in female desire: "A young man passed by / My heart went in pursuit of him / He disappeared, you could say, a cloud-like thing / And I stayed to give a description of him." ${ }^{18}$ M'Hamsadji concludes that most

17 In Fez, Morocco, the sister city culturally and linguistically to Tlemcen, Algeria, a parallel female ritual minus women's poetry is described in Edward Westermarck's, Ritual and Belief in Morocco (New Hyde Park, New York: University Books, 1968), vol. 1, 358-359. Information wanted by women through divination is given by the jinn according to songs and music randomly heard, not performed, by the women. If a female client hears a funeral dirge, the interpretation is about death in the future.

18 Kacimi and Koraichi, Bouqala, unpaginated. My translation. 
of his radio-based corpus of poems was about love, but an innocent idealized love, while remaining poems from his collection highlight themes of religion, fate, happiness, sadness, deception, adversity, and descriptions of nature and gardens.

M'Hamsadji's interpretations disavow the būqālah's open expressions of magic, female sexuality, and religious irreverence characteristic of oral literature and performance. ${ }^{19}$ Women proclaiming sensual descriptions and erotic feelings, a characteristic of female-performed genres cross-culturally, are expressed not only in the būqālah but shared across Algerian oral expressions. The following example of a linguistic transcription using the Latin alphabet, followed by both Arabic script for the poem and French translation is from William Marçais' 1902 volume on the Tlemcen dialect and appears in many subsequent collections:

\section{XXII}

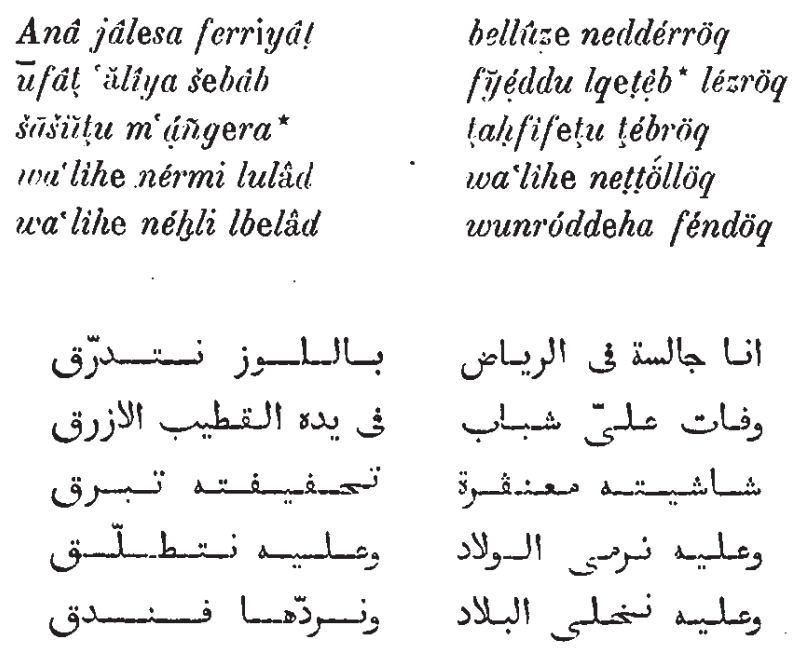

Une femme mariée chante :

Assise dans le jardin, cachée derrière un amandier, j'ai vu passer un jeune homme, tenant à la main une baguelle verte;

Sa chechia fièrement rejetíe en arrière laissait luire son front rasé.

Pour lui j'abandonnerais mes enfants et je me ferais répudier:

pour lui je rendrais la ville déserte et j'en ferais un fon$\operatorname{douq}(1)$.

19 M'Hamsadji argues for the "healthy atmosphere" in which the būqälah are chanted, 46-47. 
I am sitting in the garden / hiding by an almond tree // And a young man passed me by / in his hand a green staff // His chéchia slanted back / his pate glitters // And for him I would throw away my children / and for him get divorced // and for him empty the town / and turn it into an inn. ${ }^{20}$

Drawing on fieldwork in the western city of Tlemcen, literary scholar Mourad Yelles-Chaouche's comprehensive 1990 study provides eleven versions of female sexual passion wreaking the same havoc as in Marçais' būqālah text but circulating in another genre of Algerian women's poems known as hawfi."21 The popularity of this theme leads Yelles-Chaouche to conclude that women's hawfi, characteristic of urban Tlemcen, demonstrates "polyvalence" through textual borrowings across a wide variety of North African women's oral poetic genres. He envisions a vast and integrated, feminine poetic repertoire of related and overlapping contents, at once multi-functional and multi-purpose. A lullaby's lyrics, a pilgrimage song, the būqālah and hawfì, all incorporate proverbs and sayings, shared themes and vocabulary, whether they are deployed to rock a child to sleep, sing in the garden on a swing or seesaw, divine the future, ask for saintly intercessions during visits to local shrines, or express sexual desire. ${ }^{22}$

Transformations in the Būqälah Archive:

The Absence of Magic and the Presence of Men

For Western, colonial-era ethnographers such as Desparmet, Grand'Henry, and Westermarck, magic is obviously at play because women participants believe that jinn inhabit the būqālah pitcher, ever present to be invoked and activated. This proposition that poeisis and divination emerge from the būqālah's magical powers is one that will be disputed by subsequent Algerian writings. In

20 Marçais, Le dialecte arabe parlé à Tlemcen, 236-237, numbered XXII in his collection. My English translation is based on texts provided by Marçais in the form of his transliteration, transcription into Arabic script, and French translation.

21 Mourad Yelles-Chaouche, Le Hawfi: Poésie feminine et tradition orale au Maghreb (Algiers: Office des Publications Universitaires, 1990), 246 and Bencheneb, "Chansons de l'escarpolette," 97.

22 Scholars who have noted that the būqälah overlaps with the hawfi are Saadedine Bencheneb, "Des moyens de tirer des présages au jeu de la buqala," 13 and Yelles-Chaouche, Le Hawfi, 40-43 and 16-162. See also Mourad Yelles, "La cour et le jardin: Lyrique andalouse et poésie feminine au Maghreb," Horizons Maghrebins: Le Droit à la Mémoire 47 (2002): 109-116; and Mohamed Elhabib Hachlaf, El Haoufi, chants des femmes d'Algérie (Algiers: Alpha, 2006). 
contrast to colonial ethnographies, researchers note the absence of magic during the büqälah ritual, linking the change to men's presence. ${ }^{23}$ Some scholars emphasize the physical absence of males, excluded from the traditional enclosed world of women and būqālah divinatory entertainments "rooted in women's time that women protected from outside interference," ${ }^{24}$ while in contrast, literary scholar Saadeddine Bencheneb conjectures that even in the late nineteenth century, women's poetry became increasingly available and known to men: "Quatrains circulated outside of the group of the initiated even among men who, finding them pleasant, collected them and even imitated them." 25 Indeed, oral literature, no matter how familiar, traditional and seemingly restricted to one gender, lends itself to spontaneous adaptation in both performance and writing as well as by choice of venue, speaker, and language register. The presence of versatile functions and variable themes along with the balance of creativity and tradition serve to challenge the notion that feminine poetry circulated only among women who focused on the subjects of men and amorous encounters replete with sexual and sentimental allusions. Therefore, based on evidence from content borrowings, genre overlapping, and cross influences between male and female folk literature, Yelles-Chaouche conjectures that over time the magical, divinatory aspects of būqālah lessened in favor of an expressive and playful oral poetry shared by men and women. ${ }^{26}$ The presence of men is interpreted either as the cause or perhaps a manifestation of the būqālah's diminishing attachment to its originary magical aspects.

The argument against magic finds its most trenchant advocate in Frantz Fanon, for whom anything supernatural represented the escapist atmosphere always found among subalterns. According to Fanon, who penned his analysis in the midst of the Algerian independence war against the French, būqālah rituals are wasteful, oneiric pastimes that substitute for the difficult struggle toward emancipation required of subjugated, colonized nations:

The atmosphere of magic and myth frightens me and so takes on an undoubted reality. By terrifying me, it integrates me in the traditions

\footnotetext{
23 See the discussion on male composition of Bedouin short poems known as "ghinnawa" in Lila Abu-Lughod, Veiled Sentiments: Honor and Poetry in a Bedouin Society (Berkeley: University of California Press, 1986), 186-213.

24 See the discussion by Marnia Lazreg, The Eloquence of Silence: Algerian Women in Question (London: Routledge, 1994), 112. Minus the būqālah pitcher, Lazreg describes a similar female ritual of divination and poetry in Mostaganem, Algeria, 111.

25 Bencheneb, 31-32.

26 Yelles-Chaouche, Le Hawfi, 162.
} 
and history of my district and tribe, and at the same time it reassures me, it gives me status, as it were an identification paper. In underdeveloped countries the occult sphere is a sphere belonging to the community which is entirely under magical jurisdiction.... The supernatural, magical powers reveal themselves as essentially personal; the settler's powers are infinitely shrunken, stamped with their alien origin. We no longer really need to fight against them since what counts is the frightening enemy created by myths. We perceive that all is settled by a permanent confrontation on the phantasmic plane. ${ }^{27}$

Algeria's vast cultural and psychological alienations caused by a repressive French settler-colonial political economy influenced Algerian women's status, similarly structured by multiple exclusions and entrenched patriarchies whether colonial or homegrown. Recourse to the supernatural, according to Fanon, would then be understood as the inevitable response of the colonized Algerian woman. In contrast, the role of women, Fanon famously counseled, should be to fulfill auxiliary supporting roles that channel feminine opposition to the French colonial enemy:

It has always happened in the struggle for freedom that such a people, formerly lost in an imaginary maze, a prey to unspeakable horrors yet happy to lose themselves in a dreamlike torment, such a people becomes unhinged, reorganizes itself, and in blood and tears gives birth to very real and immediate action. Feeding the moudjahidines, posting sentinels, coming to the help of families which lack the bare necessities, or taking the place of a husband who has been killed or imprisoned: such are the concrete tasks, to which the people is called during the struggle for freedom. ${ }^{28}$

While Fanon acknowledges possibilities for ritual and magic as potentially powerful wellsprings to bring about armed uprisings against a colonial imperial order, Algerian writer Laadi Flici was among many researchers who joined Fanon in de-emphasizing magic.

Flici, rather pointed to the random qualities of the būqālah as a game. In addition, he favored the role of poetry as a force with which to educate a generation of Algerians newly freed from colonial rule:

\footnotetext{
27 Frantz Fanon, The Wretched of the Earth (New York: Grove Press, 1963), 55-56.

28 Fanon, ibid., 57.
} 
A room. Candles. A brazier. A boqala. A female assistant. Benzoin. Fumigation. Poems ready to be started. The stage set. The condition. A ritual to respect. Then it is the "invocation" phase just after the fumigation. The game of boqala. The game of oral poetry. A millennial game. It is a game. An EDUCATIONAL game. Nothing in the hands. No magic. No sorcery. A brazier with coals. ${ }^{29}$

The rhetoric against the presence of magic in būqālah poetry performances by writers such as Frantz Fanon and Laadi Flici may reflect historical transformations in the ritual. Yet in confronting what appeared to be the world of Algerian women's superstition and irrational belief in divination, these researchers were also heralding a shift in emphasis away from magic and toward the power of poetry and its potential role in indigenous resistance.

\section{Algerian Women's Poetry as Cultural Resistance}

During the Algerian liberation war from France, the būqālah poem and rite, always oral and in Algerian Arabic, included males, although genuine poetic improvisations were deemed the purview of females. The Algerian war had cut into leisure activity: male and female urban dwellers disappeared into the resistance or the countryside, while constant French curfews and night patrols eliminated the safe routines of urban evening gatherings. Despite population lockdowns, būqālah poems were still recited in wartime Algeria from the 1950s, but the emphasis shifted from predicting a man's love to divining the safety of the male fighter and the beloved's whereabouts in the army of resistance. A feminine game once linked to orality, the occult arts, and poeisis began to bear new political burdens.

In similar ways cross-culturally and historically, numerous national movements appropriated and transfigured vernacular authenticity when repurposing folk songs and folk poetry into the service of nationalist, revolutionary agendas and ideals. Folklore scholar Regina Bendix terms folklore's continued importance in the search for cultural and linguistic authenticity an "emotional and moral quest":

Folklore has long served as a vehicle in the search for the authentic, satisfying a longing for an escape from modernity. The ideal folk community, envisioned as pure and free from civilization's evils, was a metaphor for

Flici, Sous les terrasses d'antan, 33. 
everything that was not modern. Equally relevant is folklore's linkage to politics, where authenticity bestows a legitimating sheen, with political change linked to modernity, affirmatively in revolutions, negatively in counterrevolutions. The most powerful modern political movement, nationalism, builds on the essentialist notions inherent in authenticity, and folklore in the guise of native cultural discovery and rediscovery has continually served nationalist movements since the Romantic era. ${ }^{30}$

Texts derived from the performed expressive culture of the būqālah that inextricably linked Algerian women, the Algerian Arabic dialect, poetry, and women's sexuality underwent a process of transformation into symbols of national resistance and unity. Not only did gendered social disruptions during wartime affect the production of būqālah poetry and performance, in addition, independence and post-independence nationalist projects sustained the colonialera linguistic shift that privileged modern literary Arabic over Algerian Arabic dialect. In post-independence Algeria from 1965 under President Houari Boumedienne (1965-78), a specific version of Arabization gained momentum to the detriment of spoken languages. Historian of Algeria Hugh Roberts summarizes restrictive post-independence linguistic policies:

The Arabisation policy was based on the premise that neither French nor the colloquial Arabic and Berber spoken in Algeria could serve as the language of education and administration. Its aim was accordingly to make the modern literary Arabic, which had been developed as the lingua franca of the Mashriq, the national language of Algeria. ${ }^{31}$

A cultural revolution to accompany the country's radical economic, foreign, and linguistic policies served to elide Algerian Arabic dialect, the Amazigh (Berber) language, and French-idioms spoken by many Algerians as their first or second tongue. This enforced officially-sanctioned replacement, often referred to as the "linguicide" 32 of primary languages in favor of literary Arabic (no Algerians' mother tongue), was accompanied by national attempts throughout the 1970s to "folklorize" Algeria's heritage. Scholar and professor of Arabic Aida Bamia, who lived in Algeria and taught a class in Algerian folklore

$30 \quad$ Regina Bendix, In Search of Authenticity (Wisconsin: University of Wisconsin Press, 1997), 7.

31 Hugh Roberts, The Battlefield: Algeria 1988-2002 (London: Verso, 2003), 12-13.

32 I borrow the term from Djamila Saadi-Mokrane, "The Algerian Linguicide," in Algeria in Others' Languages, ed. Anne-Emmanuelle Berger (Ithaca: Cornell University Press, 2002), see especially her discussion in 44-59. 
at the University of Constantine in the early 1970s, recalls the first, albeit shortlived, national campaign spearheaded by the Ministry of Culture then headed by Ahmed Taleb Ibrahimi. The belief in the necessity of a "cultural decolonization" for Algeria was prevalent, defined practically in terms of national projects to collect and preserve classic genres of folklore in writing. For Taleb Ibrahimi, "national culture is preserved in proverbs, folk songs, and all this oral literature that continues to reflect the life and struggle of the people." ${ }^{33}$

M'Hamsadji,'s radio broadcasts and accompanying volume on būqālah poetry are evidence of complex linguistic attitudes towards folk literature in Algerian Arabic during the decades of the Algerian people's struggle against colonial occupation into the post-independence era. He readily assigns latter-day politicized meanings to women's traditional cultural expressions, for example: "I climbed up to the roof terrace to capture a dove / I landed on my bed and stretched my legs / I said, O Lord, my worries have left me / I take revenge on my enemy / as he takes revenge on me."34 The slot for the "enemy" in the verse functions as a substitutable component that can be filled with a variety of antagonists - a human one such as a brother and friend opposing the love match, or a condition obstructing the lovers, for example an illness. For M'Hamsadji, larger nationalist preoccupations remain poetic obstacles to the self-realization of a people, specifically the colonialism and imperialism that exploited Algerians for 130 years. ${ }^{35}$ Nonetheless, interpretations offered in his broadcasts and book were conducted in French, thereby continuing the academic study of popular culture and poetry of the Algerian Arabic dialect in analytic ways that remains tied to Algeria's history of French ethnographic descriptions in the colonies. His exceptions are recitations of invocations and the būqālah poem itself which he transcribed into Algerian Arabic using Arabic script.

It is noteworthy that M'Hamsadji voiced concerns about his use of Frenchlanguage broadcasts about the būqālah, as he replicated much of Algeria's colonial-era tripartite linguistic division: French was the foreign language, literary modern standard Arabic was the national language, and Algerian Arabic, the silenced majority spoken-language. His introductory disclaimer makes clear the contradictions of Algeria's multiglossic mix:

33 Bamia, The Graying of the Raven, 4. Bamia draws on Taleb Ibrahimi's French-language publication, De la colonization à la revolution culturelle (1962-1972) (Algiers: SNED, 1973).

34 M'Hamsadji, būqālah text, 166. See also the discussions in Martine Bertrand, Le jeu de la boqala, 98 and Lazreg, 112.

35 M'Hamsadji, 61-62. 
I also was afraid to be most certainly confronted by the problem of language since the program would be broadcast in French, a foreign language in our country, at the very moment when the national language, Arabic, began to be affirmed as the official language in administration and education. ${ }^{36}$

The process to undo enduring cultural and linguistic processes carried over from colonization was of paramount importance. Frantz Fanon's chapter titled "On National Culture" in The Wretched of the Earth details Algeria's inevitable successor stages. What once constituted a colonial culture that "turns to the past of the oppressed people and distorts, disfigures, and destroys it," was to be followed by an independent, nationalist Algerian regime that, in turn, would attempt to reconstitute and glorify oral traditions nostalgically. ${ }^{37}$ Indeed, if post-independence Algerian cultural brokers looked to women's oral tradition in different ways from the colonizers' collections of oral traditions and customs of the "natives," the outcomes of their textual production (Arabic text, Latin letter transliterations, French translation) appear identical.

In the early decades after independence throughout North Africa, stateappointed, regime-controlled official folklore programs proliferate. Run by folklorists, they were involved in descriptive studies of crafts or collecting oral literature in praise of the state. In contrast, Tunisian folklorist Abderrahman Ayoub espoused the "politicized" Maghribi folklorist, one cognizant that the rich archive created by Orientalists during colonialism "constitutes a primary source for the study of Arab-Muslim cultural patrimony, [and who] must ask these questions: How have the products of oral and material culture been passed down to us? Why have they come down to us and continued to be transmitted, despite historical circumstances that have tried to eliminate them?"38

\section{Būqālah: A Francophone Algerian Poem}

In 1962, the first year of Algerian independence, a būqālah poem passed into written French from spoken Algerian Arabic in dramatic and far-reaching ways. Awarded a literary prize, it was published in the October issue of the presti-

$36 \quad$ M'Hamsadji, 92.

37 Fanon, 210.

38 Abderrahman Ayoub, "The Arab Folklorist in the Postcolonial Period," in Beyond Colonialism and Nationalism in the Maghrib: History, Culture, and Politics, ed. Ali Abdullatif Ahmida (New York: Palgrave, 2000), 42-43. 
gious francophone magazine, Jeune Afrique. Literary critic Christiane Achour celebrated the poem, titled "Boqala," as one of the most beautiful literary artifacts emerging from the Algerian war. ${ }^{39}$ The poem's author explicitly drew on the vast resource of women's oral folklore, as if to suggest literary possibilities for decolonizing a traditional female poetic form that had been subjected to decades of assiduous collection practices. A radical revision of the Algerian būqālah, no less than the French-language poem, had emerged but not from the anonymous, feminine, poetic collectivity beloved of researchers. Instead, the known and named author, Djamila Amrane, had crafted her own reworking of the būqälah genre. By choosing the French language and because of her complex personal history, her poem continues to resonate between France and Algeria, French and Algerian Arabic, writing and orality, performance versus text, and female folkloric genres and male appropriations and analyses.

Amrane, labeled either a criminal terrorist or an Algerian freedom fighter, ranks among a long list of famous women activists, moudjahidate and chahidate, fighters and martyrs, who fought for Algerian independence. ${ }^{40}$ Many became well-known published writers and poets. Among francophone Algerian authors are counted Jacqueline Guerroudj, Annie Steiner, Anna Greki, Leila Djabali, Myriam Ben, and Zhor Zerari. They were pied-noirs as well as Algerian Muslims and Jews who shared the status of being female former political prisoners. ${ }^{41}$ Djamila Amrane was born in France as Danièle Minne. She and her mother, Jacqueline Netter-Minne-Guerroudj settled in Tlemcen, both married Algerian men, and took Algerian nationality and identity. They were imprisoned together as a result of their activities in the urban bombing network of the Front de Libération Nationale (FLN, Algerian Liberation Front). ${ }^{42}$ For readers familiar with the film The Battle of Algiers in which three women descend from the Casbah to plant explosives in three cafés in the city's European neighborhoods, director Gillo Pontecorvo recreated a powerful cinematic moment based on Amrane's bomb device which she, at age seventeen,

39 Christiane Achour, Anthologie de la littérature algérienne de langue française (Algiers: Entreprise Algérienne de Presse, 1990), 283.

40 I retain French-inspired transliterations for mujāhidāt and shāhidāt. See writings by Djamila Amrane, Les femmes algériennes dans la guerre (Paris: Plon, 1991) and Desfemmes dans la guerre d'Algérie (Paris: Karthala, 1994). Under the name Danièle Djamila AmraneMinne, she wrote "Women and Politics in Algeria from the War of Independence to Our Day," Research in African Literatures 30 (1999): 62-77.

41 Christiane Achour et al., ed., Diwan d'inquiétude et d'espoir: la littérature féminine algérienne de langue française (Algiers: ENAG-éditions, 1991), 217-232.

42 Andrée Dore-Audibert, Des Françaises d'Algérie dans la guerre de libération (Paris: Karthala, 1995), 144-156. 
placed in the café-milk bar Otomatic on January 27, 1956. Captured and tried as a minor, she was incarcerated for seven years in Algiers, then in French prisons along with her mother, Jacqueline Guerroudj, and other female Algerian political prisoners. ${ }^{43}$ All were amnestied as part of the 1962 Evian Accords that officially marked the war's end, Algerian independence from France, and the liberation of all Algerian political prisoners detained in the metropole. In the immediate post-independence years, literary pioneers who produced a critical mass of writing were drawn from the circle of women fighter-prisoners, many penning their experiences about the 1954-62 war years. Amrane's poem, "Boqala," appeared six months after her April 1962 liberation from the French prison of Rennes and her subsequent repatriation to Algeria.

Awarded the first prize in poetry, Amrane's "Boqala" was republished in the seminal francophone Algerian anthology on the literature of the war, Espoir et parole. ${ }^{44}$ The publication of poems in an anthology by Algerian women expolitical prisoners reflects the on-going, post-World War II dissemination of the literature of witness and resistance. American poet Carolyn Forché sets forth her major premise about the poetry of witness, which is the willingness to give primacy to a poem's consequences over its truth value:

To talk about a poem as the sole trace of an event, to see it in purely evidentiary terms, is perhaps to believe our own figures of speech too rigorously. If, as [Walter] Benjamin indicates, a poem is itself an event, a trauma that changes both common language and individual psyche, it is a specific kind of event, a specific kind of trauma. It is an experience entered into voluntarily. Unlike an aerial attack, a poem does not come at one unexpectedly. One has to read or listen, one has to be willing to accept the trauma. So, if a poem is an event and the trace of an event, it has, by definition, to belong to a different order of being from the trauma that marked its language in the first place. ${ }^{45}$

A poem, Forché argues, may be our only documentary evidence that a specific and violent event occurred. Forchés example is the poem found on the exhumed corpse of Hungarian Jewish poet Miklós Radnóti, shot in the neck

43 On memoirs of the women's political prison experience, see Jacqueline Guerroudj, Des douars et des prisons (Algiers: Bouchene, 1993).

44 Djamila Amrane, "Boqala," in Denise Barrat, Espoir et parole: Poèmes algériens (Paris: Seghers, 1963), 147-151.

45 Carolyn Forché, "Introduction," in Against Forgetting: Twentieth-century Poetry of Witness (New York: W.W. Norton, 1993), 33. 
in 1945 during one of the last Nazi death marches. His poem is the only documented description of his torture and the death he foresaw is a death foreseen in his own writing. Radnóti's few verses commemorated the death of his fellow camp inmate, the violinist Miklós Lorsi. Radnóti managed to scribble some words on a piece of paper only retrieved from his coat pocket after his murder: "I fell beside him; his body turned over / already taut as a string about to snap / shot in the back of the neck / that's how you too will end, I whispered to myself; just lie quietly / Patience now flowers into death, a voice said above me / On my ear, blood dried, mixed with filth." 46

What makes Radnóti's poem comparable to the Algerian woman poet and political prisoner is the act of composing under a state of cultural siege, one that is defined as the site where the personal, the political, and the "social" space are inseparable from precise questions of geographical location and historical time - where do you live now, for whom did you write, which prison did you write it in, when and under what circumstances did you write, and even, what was the manner of your death? Amrane's "Boqala" poem, as well as her historical research, such as her 1988 doctoral dissertation, "Algerian Women and the War of National Liberation, 1954-62," share with the Radnóti poem the notion of writing as a record of experience, a call to strength in the face of torture, and oral testimonials in the absence of any other kind of proof. ${ }^{47}$

At the same time, Amrane's poem, although rooted in the historical moment of Algeria's triumphant 1962 year of independence, borrows from the būqālah genre in order to register simultaneously the joy of her country's liberation from France and her own release from seven years of prison, and to capture the extensive losses of the Algerian male war dead. Amrane takes up the traditional female būqālah poem, stripped of magic and divination, through a series of ingenious counterpoints and elaborations. Her refrain exemplifies the ways in which she inhabits the structural poetic dynamics of the büqälah that had come to accommodate the lived effects of colonialism and war: "J'ai ramené la boqala du puits / Chaque goutte qui en tombait / Portait le nom d'un frére tué / Je l'ai ramenée toute ruisselante à la maison / L'eau en était fraiche et parfumée" (I brought back a būqālah from the well / Each drop that from it fell / Carried the name of a brother killed / I brought it to my house as it trickled down / Its waters fresh and perfumed). Her poem is referentially folkloric and oral, hewing closely to aspects of the formal poetic structure of the

46 Ibid., 29-30.

47 For an extended discussion of the literature of witness in the Maghribi context, see my The Performance of Human Rights in Morocco (Philadelphia: University of Pennsylvania Press, 2005). 
traditional women's būqālah. Amrane submerges her identity in alternations between poetic invocations and prose commentary, while branding the traditional form with her authentic voice and notable history as an Algerian political detainee in French prisons. She does so by appropriating, recombining and updating the traditional prose interpolations of the mistress of ceremonies. Her poem belongs to the world of explicit poetry of protest and political commitment that works at some level to defamiliarize the traditional and unmake colonialism.

Christiane Achour unpacks the layered density of Amrane's poem: Amrane's art is to create a human recipient-listener of the būqälah who becomes the receptacle of memory as the būqa lah pastime itself is structurally transformed into a poem. M'Hamsadji had already noted the initiating of formulas for the traditional būqālah, characteristically one in which women demand news and an accounting of their menfolk. The structured formula is: "We have subjected you to the smoke of benzoin, bring us news from the cafes," in which substitutes for the slot "benzoin" are the various perfumed incense during the ritual. Similar paradigmatic variations allow for news to be brought about events in Algiers, male fighters, or an individual household. ${ }^{48}$ Like the būqālah mistress of ceremonies, Amrane gives an answer to the questions posed by those many women who used the būqālah to peer into the future:49 "O my sisters, my soul is in pain, what will the boqala tell next? / How beautiful is the dove / the dove released from its cage / tell me, $\mathrm{O}$ dove / Who gave you these grains / when you were in pain / Who gave you some water / When you were on high / On high in our hills? / O my mother, there's no more oppression / O people, we're better than we once were / Who gave you these grains when you were in pain? / Slimane, wounded, you're dead / because we could not attend / no, my sisters, I cannot be cured / I have brought back a būqälah from the well / Each drop that from it fell / Carries the name of a brother killed / And each one of these drops / burns me for all time." The result is both new and familiar, a poem looking backward that names and details the histories of loved ones killed in combat, and to a future in which romance may unfold, governed by the edicts of magical predictions. Inserted in the middle of the poem are despairing prose passages to describe the male revolutionary-martyr's death, as if poetic performance were a living tradition to incorporate female commentaries and exchanges entirely absent from colonial and post-independence text collections:

48 Selected invocations are collected in M'Hamsadji, 38-39.

49 Christinae Achour, Abecedaires en devenir: Idéologie colonial en langue francaise en Algérie (Algiers: Entreprise Algérienne de Presse, 1985), 490-491. 
Slimane, wounded, you are dead, because we could not take care of you. The shelter of the village Chaouchines, one of our worst shelters, a narrow trench of three meters and a hole at the bottom. It was there I found you, Slimane, lying on a wooden bed, you were wounded in the chest by an exploded bullet. Only your hand molded in mud appeared alive, your face a cry of sadness. We stayed there a long time, and then, slowly you began to speak; it was independence, you were returning to your village, in front of our door my mother with our flag ... you smiled and fell asleep. When I returned, Slimane, you were dead. Your hand filled with mud, limply outstretched lifeless and a large tear stopped on your cheek. ${ }^{50}$

Through Amrane's poem and just mere months after the 1962 independence, the formation of a post-colonial Algerian literary and national identity began to emerge through the production of new poetic texts that revealed novel cultural riches. In 1999, Amrane left Algeria for France during her adopted homeland's murderous internal wars of the 1990s that claimed more than 200,000 Algerian dead including many writers, journalists, artists, and educators. She took up a teaching post at the University of Toulouse, France and was part of the decade-long intellectual brain-drain during which thousands fled their homeland. In Amrane's case, her move was exceptional, as France recalled the history of a French-born, Algerian-identified, seventeen-year-old responsible for the 1956 Battle of Algiers milk bar explosion. An unsuccessful campaign was launched to remove her from her university position under the rubric of "Amrane the terrorist."

Despite these contemporary re-readings, her 1962 "Boqala" poem, indeed all her writings, continue to remind readers of the powerful literary impact of Algerian women's poems, letters, memoirs, and drawings composed in prison, whose emergence and publication histories need to be considered alongside their content. This too is the fate of the oral traditional forms of būqālah poems. For oral performed rituals, polysemic interpretations derive not from reading but hearing the punned, performed versions, an orality that plays with multiple political and sexual allusions far removed from the sterility of fixed written redactions and collections. Amrane's francophone "Boqala" poem on behalf of the Algerian war of liberation, as well as traditional Algerian Arabic būqālah poems by women, frame possibilities for meditating on the degree to which poems and performances, texts and contexts are part of a complex dynamic where folk and popular histories in Algerian Arabic, accompanied by French translations and expositions, have been traditionally and ethnographically

Amrane in Barrat, 151. 
opposed to written official Modern Standard Arabic literature. In the case of Amrane's poem, Algerian Arabic is on the side of French for academic and poetic recognition. Linguistic exchanges on the Internet where būqālah poems re-circulate orally and in writing make clear that Algerian Arabic and French have vanquished literary Arabic. Furthermore, when the fighter and martyr became model figures for Algerian poetry written by women prisoners, Amrane's "Boqala" poem documents extreme conditions through the literature of witness, laying bare connections between an individual martyr-fighter and the collective Algerian fate. In more specific ways, Amrane's būqālah poem of martyrdom and sacrifice, the stuff of her time in prison, comes to remind us of the ways in which poets present an individual poetic self, yet at the same time establish a powerful voice on behalf of the unwritten, orally declaimed collectivity. 